\title{
TEACHING STUDENTS' VOCABULARY THROUGH TOTAL PHYSICAL RESPONSE
}

\author{
Risma Gayanti ${ }^{1}$, Intan Satriani² \\ ${ }^{1}$ IKIP Siliwangi \\ ${ }^{2}$ IKIP Siliwangi \\ ${ }^{1}$ rismagayanti490@gmail.com, ${ }^{2}$ intansatriani@ikipsiliwangi.ac.id
}

\begin{abstract}
Learning English during this time globalization is exceptionally critical. People aspire to speak fluent in English. This proves that the presence of English during this time globalization is exceptionally imperative and considering that English is an international language. However, many Indonesians people cannot master vocabularies well, due to lack of understanding when studying in the class. The population of students were 130 within the eighth grade, but researcher using 1 class, there are 35 students within the class for this study. Thereby, the aims of this research is to find the vocabulary improvement of Total Physical Response (TPR). The researcher used qualitative method. Interview and test used as instrument of this research.The result showed that students more understand and truly remember of recent vocabularies when using Total Physical response (TPR) as a way. It can be concluded that students can improved their vocabularies well through TPR.
\end{abstract}

Keywords: Vocabulary, Total Physical Response

\section{INTRODUCTION}

English is used either verbally or in written form in many practices Atikah (2019). English is incredibly necessary within the current era of globalization, as a result of English is a global language utilized by all countries to speak. Several translator square measure learning varied languages to become their current job. Since many people still are not able to communicate in English. With this, the researcher need to alter the propensity of understudies, to form they can utilize English as well. There is teaching some fun methodology to build their vocabularies well and make them perceive what the means of words.

Teaching is utilized to transfer information from teachers that square measure designed used methodology, some material and technique to enhance students' ability. Teaching is showing or serving to somebody to do one something, giving instruction, guiding throughout this study of something, providing with the data inflicting, Sinaga \& Safitri (2018).

Vocabulary is the learning of fundamental language, whether the vocabulary is the first, the second, or the foreign language (Nuraeni \& Lube, 2020). Vocabulary is incredibly important to find out four skills in English, there are listening, speaking, reading and writing. Without language structure exceptionally small can be passed on, without vocabulary nothing can be passed on (Ngarofah \& Sumarni, 2018). Vocabulary exceptionally is a critical part in communication with individuals within the world (Ibrohim \& Septianti, 2018).

Without vocabularies, understudies ought to know more approximately vocabulary to begin with, they are will effectively to get it around in few writings or indeed they can talk or tuning in a few discussions. Vocabulary really important thing of language skill basic to increase learner's listens, speak, read and write (Setiawan, 2018). 
Furthermore, vocabulary may be a set of words known to an individual or other eternity, or that are parts of a particular language (Handayani \& Muddin, 2018). And the others said that the basic of language is vocabulary. Which is verb, adverb, adjective, and noun is the type of vocabulary that able to make a language important (Rahmawati \& Utami, 2019).

It implies that vocabulary is exceptionally imperative to master the four abilities of English. Without vocabulary, students cannot master any English abilities. In Indonesia, understudies favour other subjects to learn. Since they believe that learning English exceptionally troublesome. The role of teacher is important to increase students' confidents and make them want to learn English more.

Students ought to learn English wit fun methodology, since students are effectively to induce bored when they are leaning.

Many students will interested with method that can make them happy, like doing a body movement, speak loudly about something while they are move or demonstrate something. It makes students more certain and simple to keep in mind unused words since they are learn it with movement, talks moreover listened at the same time. With this, the researcher took Total Physical Response (TPR) as a method. James Asher is found Total Physical Response as a classroom research for communicated of youthful learners with the teacher and their friends. $\mathrm{He}$ is a San Jose University's pf physiology. It is how teacher is instructing the students should response the instruction. Either in movement, orally, or heard.

TPR maybe a method of instructing language utilizing physical development to respond to verbal input in arrange to decrease students' restraints and lower their effective filter (Hidayat \& Munandar, 2018). The other expert is implying that Total Physical Response is a language teaching centered around speech and action coordination' its attempts by physical motor movement against each language (Ibrohim \& Septianti, 2018). This methodology does not require much preparation if teachers choose to teach a variety of student materials and this methodology is very useful for teens and youthful learners.

\section{METHOD}

Researcher using this method to improves student vocabulary mastery. This research is about understanding the Total Physical Response will or will not increase student vocabulary. Researcher used descriptive qualitative as a research method. The researcher utilize this inquire about method is for displaying understudies enhancement to their vocabulary dominance. Qualitative research has a common setting as the coordinate source of information and the researcher is the key of instrument (Lelawati et al., 2018).

In research instruments, researchers use interview to retrieve data on students. The interview is strategy a gather of procedures particular to the uncommon and human science (Ibrohim \& Septianti, 2018). Researcher will examine how students' opinions about vocabulary learning use TPR methodology and take 9 opinions contained within the class to be referred to whether students like the learning method or not.Through this interview too, can help improve the quality of learning expected of students within the course.

A population is a gather of component or cases, whether people, object, or evens that acclimate to particular criteria and to which we aiming to generalize the result of the research (Ibrohim \& Septianti, 2018). Population is the group of interest to the researcher, the group to whom the researcher would like to generalize the results of the research (Hidayat \& Munandar, 2018).

With the population taken as an example of research are $8^{\text {th }}$ grade students totalling 35 students. 
The sample can be chosen from a bigger gather or people, recognized as the populace or it can basically allude to the bunch or subjects from whom information are collected indeed in spite of the fact that the subjects are chosen for population (Ibrohim \& Septianti, 2018).

Sample of this research is $8^{\text {th }}$ review understudies who sum up to 35 understudies to discover out whether learning vocabulary with a TPR methodology can make understudies way better get it or not.

This is the step how to teach student with Total Physical Response (TPR) method :

1) Doing an introduction about the method

The teacher introducing the method to the understudies, this aiming to make students know and understand about the purpose of the method and know how to learn some vocabularies using TPR. This is the basic to teach the students about the method, if the educator can deliver the meaning of this methodology clearly, students can easy to understand when the materials are taught.

On this steps teacher role is a model for explaining the material using (TPR) method.

2) Make a small discussion about the material.

The step is to make sure that students really understand what the $1^{\text {st }}$ step talking about. This step is to make students more understand about what (TPR) are, and they make a small discussion for learn new words, this is aiming for students practice a new vocabularies with this method.

3) Students demonstrating their discussion

This is the last step of Total Physical Response. In this step students demonstrate or do what the teacher do as a model.

If the students follow the right instructions same like the teacher do, with that students is understand how to learn vocabularies with this method.

The educational of process is successful.

\section{RESULTS AND DISCUSSION}

\section{Results}

This is table the result how Total Physical Response impact to students vocabularies and value on the class.

Table 1. The activity of Meetings

NO Meetings Description




\begin{tabular}{ll}
\hline 1. Meeting 1. & At the first meeting, researcher roleplayed \\
as a model. Explain how (TPR) works in \\
the classroom. The researcher give an \\
outlined of the Total Physical Response \\
(TPR) methodology by giving pictures or \\
some texts linked to the material. Then give \\
examples of pronunciation and invited \\
students to follow the leading of the \\
researcher. This section is actually \\
significant part, so the students can \\
understand how to utilize this method. If at \\
this stage students can understand, they will \\
be surer in the next meeting when using this \\
method. \\
At the second meeting, the researcher \\
recalled what had been learned at the \\
previous meeting and give direction to look \\
for meaning of the material provided and \\
students are encouraged to write, interpret \\
and modelling the material that has been \\
given.
\end{tabular}

Simultaneously at the $5^{\text {th }}$ meeting, the researcher randomly called students in class to take part in casual interviews about the material being taught used by the TRP Method. 
The output of the interviews, 8 out of 9 people who taken part of the interview said, they better understand vocabulary learning using (TPR) Method. Because the method is fun and does not make students feel bored or sleepy. Students recommend others materials using this method.

This is the result of the research for one month at the 8 students of Junior High School that researcher taught.

Table 2. The result of Final Test.

\begin{tabular}{|c|c|c|}
\hline Number & Students & Final Test \\
\hline 1. & Student 1 & 99 \\
\hline 2. & Student 2 & 98 \\
\hline 3. & Student 3 & 98 \\
\hline 4. & Student 4 & 95 \\
\hline 5. & Student 5 & 85 \\
\hline 6. & Student 6 & 90 \\
\hline 7. & Student 7 & 99 \\
\hline 8. & Student 8 & 85 \\
\hline 9. & Student 9 & 85 \\
\hline 10. & Student 10 & 98 \\
\hline 11. & Student 11 & 90 \\
\hline 12. & Student 12 & 85 \\
\hline 13. & Student 13 & 78 \\
\hline 14. & Student 14 & 80 \\
\hline 15. & Student 15 & 98 \\
\hline 16. & Student 16 & 79 \\
\hline 17. & Student 17 & 90 \\
\hline 18. & Student 18 & 95 \\
\hline 19. & Student 19 & 95 \\
\hline 20. & Student 20 & 98 \\
\hline 21. & Student 21 & 90 \\
\hline 22. & Student 22 & 92 \\
\hline 23. & Student 23 & 96 \\
\hline 24. & Student 24 & 98 \\
\hline 25. & Student 25 & 95 \\
\hline 26. & Student 26 & 90 \\
\hline 27. & Student 27 & 95 \\
\hline 28. & Student 28 & 98 \\
\hline 29. & Student 29 & 95 \\
\hline 30. & Student 30 & 95 \\
\hline 31. & Student 31 & 90 \\
\hline 32. & Student 32 & 98 \\
\hline 33. & Student 33 & 95 \\
\hline 34. & Student 34 & 90 \\
\hline 35 & Student 35 & 98 \\
\hline
\end{tabular}

Based on the data attached, the students more understand the materials by using vocabulary using Total Physical Response (TPR) and this method is effective to improve student vocabulary mastery. 


\section{Discussion}

There are some significant differences when researchers observe students in class. Understudies tend to be confused and not confident when researcher asks about some vocabulary to students. They lean toward to be silence and fear of mentioning the vocabulary itself.

However, after researcher teaches vocabulary using Total Physical Response (TPR) method, students experienced an increase in learning vocabulary. Students who used to tend to be quiet and afraid to express their opinions, are presently more confident and do not feel pressured anymore. That way, (TPR) method is very helpful for students in learning vocabulary. Students be more active, easily to memorize and say many vocabulary with confidence.

\section{CONCLUSION}

In this article, teaching vocabulary trough Total Physical Response at eight grade students can offer assistance understudies learn easily, students tend to be more active when learning and can master new vocabularies. The result of this inquire about can be seen in table 2 . With a good value as a result of their final test, indicates they understand their can understand what they learn from the method.

\section{ACKNOWLEDGMENTS}

Alhamdulillahirabbil'alamin. Praise to ALLAH SWT who makes it easy to completed this paper. Peace and Solutions are always for Rasulallah SAW. Thanks to IKIP Siliwangi Bandung, especially for English Education study program. Also thanks for Mrs. Intan as my supervisor, My Family and My Friends for the supports, suggestions and motivations. Hopefully this research can be valueable for the readers.

\section{REFERENCES}

Atikah, A. (2019). Improving Students ' Vocabulary Using Poster Media For Second Grade Hearing. 2(1), 26-33.

Handayani, P. P., \& Muddin, I. (2018). Improving Vocabulary Mastery Using Picture For Second Grade Students At Slb-C Tut Wuri. 1(5), 671-676.

Hidayat, I., \& Munandar, A. (2018). Improving English Vocabulary By Using Total Physical Response ( Tpr ) Method To The Fifth Grade Students Of Sdn Pasirkaliki 1 Cimahi. 1(1), 27-32.

Ibrohim, A. T., \& Septianti, A. (2018). Students ' Perception Toward Teaching English Vocabulary Through Total Physical Response ( Tpr ) Method. 1(2), 145-156.

Lelawati, S., Dhiya, S., \& Mailani, P. N. (2018). The Teaching Of English Vocabulary To Young. 1(2), 95-100.

Ngarofah, S., \& Sumarni, A. (2018). Teaching Vocabulary Using Flashcard. 1(6), 775-782.

Nuraeni, S., \& Lube, C. I. (2020). Improving English Vocabulary Mastery. 3(1), 109-113.

Rahmawati, C., \& Utami, K. R. (2019). Improving Students 'Vocabulary Mastery Using. 2(6), 845-851.

Setiawan, J. E. (2018). Teaching English Vocabulary Using Tpr ( Total Phyisical Response) Method At The Fifth Grade Students Of Sdn Cinerang Cianjur In Academic Year Of 2017 /2018. 1(5), 696-702.

Sinaga, G. A., \& Safitri, A. N. (2018). Teaching Vocabulary Using Direct Method At. 1(5), $651-656$. 